\title{
O SISTEMA JURÍDICO APRENDE. A COMUNICATIVAÇÃO APLICADA AO PRINCÍPIO DA INSIGNIFICÂNCIA NO DIREITO
}

Artur Stamford da Silva*

\begin{tabular}{l|l}
\hline RECEBIDO EM: & 16.10 .2020 \\
\hline APROVADO EM: & 30.11 .2020 \\
\hline
\end{tabular}

* Professor titular da UFPE. Bolsista de Produtividade 1D do Conselho Nacional de Desenvolvimento Científico e Tecnológico (CNPq). Fundador da ABraSD (Associação Brasileira de Pesquisadores em Sociologia do Direito). E-mail: artur.silva@ufpe.br 
- RESUMO: Para observar como é possível o direito operar temáticas (Sacherhalt), portanto, vivenciar o processo de construção, desconstrução, reconstrução, formação, deformação e reformulação do sentido jurídico de algo, recorremos à transversalidade entre teoria social, teoria da linguagem e teoria do direito. Numa frase: pesquisamos como o direito aprende. Ao aporte teórico-metodológico, chamamos de comunicativação. Os corpora das pesquisas são decisões coletadas em sites de tribunais, vídeos das decisões disponíveis na TVJustiça, no YouTube e em documentos catalogados em sites governamentais, de instituições públicas e privadas, de ONGs, blogs etc. Sistematizados em planilha de Excel, os dados são analisados sob a ótica da comunicativação. Para demonstrarmos a viabilidade das pesquisas, apresentaremos o caso da pesquisa sobre bagatela, ou seja, princípio da insignificância no direito.

- PAlavras-chave: Decisão jurídica; transversalidade entre saberes; pesquisa empírica; bagatela; princípio da insignificância.

\section{THE LEGAL SYSTEM LEARN. THE COMMUNICATIVATION APPLIED TO THE PRINCIPLE OF INSIGNIFICANCE IN LAW}

- ABstract: To observe how is possible the legal system operate subjects (Sacherhalt), therefore, to experience the process of construction, deconstruction, reconstruction, formation, deformation and reformulation of the legal meaning of something, we resort to the transversality between social theory, theory of language and theory of law. In a sentence: we research how law learns. We call this: communicativation. The research corpora are decisions collected on Court websites, videos of decisions available on TVJustiça, YouTube and documents collected on government websites, public and private institutions, NCOs, blogs, etc. Systematized in an excel spreadsheet, the data are analyzed from the perspective of communication. To demonstrate the feasibility of research, we will present the case of research on trifle, that is, the principle of insignificance in law.

- KEYWorDs: Legal decision; transversality among knowledge; empirical research; trifle offence; principle of insignificance. 


\section{Introdução}

A aprendizagem humana pode ser tratada sob a perspectiva do behaviorismo em oposição ao construtivismo. Mas... e a aprendizagem de um sistema de sentido? Partimos do pressuposto de que a primeira frase é uma falácia porque esconde muito mais que há num processo de aprendizado a que jamais uma bifurcação de dois caminhos pode servir. Não é o caso de essas reflexões lidarem com os elementos de aprendizagem, mas com um dos temas mais interessantes que unem a teoria do direito, a prática forense e a sociologia do direito; refiro-me ao debate da decisão jurídica como espaço de atualização do direito, portanto de aprendizagem. Como lemos em obras sobre a criação judicial do direito, o direito achado na rua, o direito alternativo, o ativismo judicial e tantas outras siglas, expressões e movimentos que nos lançam em reflexões sobre a função social do judiciário, a relação direito e justiça aos moldes de autores clássicos como Rudolf von Jhering, Eugen Ehrlich, Oscar Correas, Mauro Cappelletti, Monreal Movoa, Cláudio Souto.

Ainda se reduzindo à decisão jurídica, a multiplicidade de questões e abordagens também é ampla, como as presentes em reflexões sobre a relação direito e política, direito e economia, direito e justiça. Temas como fontes do direito, norma jurídica, ordenamento jurídico e única decisão correta movem essa multiplicidade para além do âmbito jurídico atingindo reflexões sociológicas, linguísticas, políticas, econômicas, robóticas. A amplitude e multiplicidade de abordagens possíveis registram polêmicas que perseguem as pesquisas com decisão jurídica, a exemplo das polêmicas Savigny/ Thibaut (1814), Kelsen/Ehrlich (1913-1917), Kelsen/Schmitt (1931), Kelsen/Cossio (1949), Habermas/Luhmann (1970), Hart/Dworkin (1967, 1986, 1994). Não desenvolveremos reflexões sobre essas polêmicas, apenas estamos registrando que elas deram lugar às questões que norteiam as reflexões sobre decisão jurídica, principalmente quanto à possibilidade de se fazer justiça tomando decisões (casos futuros) baseadas em critérios (fatores do passado) predeterminados. Entendo que essas polêmicas registram a pretensão de se estabelecerem modelos de observação da decisão jurídica, portanto se desenvolveram por meio da defesa de um ou outro modelo de vida em sociedade, afinal, direito não é tecnocratizável, nem para quem acredita que legislação é suficiente para nortear todas as decisões jurídicas possíveis, salvo se essa fé não tenha qualquer relação com a prática forense. Fundamentais, necessárias e indispensáveis, essas polêmicas partem de dicotomias e se ocupam em defender um de seus lados. Ocorre que 
não temos a veleidade de defender a justeza de uma decisão, nem acusar decididores, mas sim pesquisar, observar como é possível a decisão jurídica ter sido tomada como foi; como é possível a construção de sentido jurídico de algo; como é possível o direito aprender como aprende. Com isso, apenas faço registrar que não partimos para as pesquisas com pressupostos de justiça, de sociedade, de direito, mas largados à coleta de dados dispostos a observá-los sem preconceitos. Por mais que eu tenha minhas opiniões sobre justiça, direito e sociedade.

Para pesquisar como o direito vivencia a construção de sentido jurídico via a tomada de decisão jurídica, recorremos a elementos da teoria do direito, da linguística, da teoria social, da epistemologia e de lógica, os quais nos levaram à comunicativação, aporte teórico e metodológico transdisciplinar.

A expressão construção de sentido aponta para o quanto a comunicativação parte da perspectiva sistêmica que tem a comunicação como célula da sociedade. Observamos comunicações, não, intencionalidade psíquica, afinal, o social é forma (SPENCER-BROWN, 1969) de comunicação e os sistemas observam (FOERSTER, 1987). Forma de comunicação indica que usamos elementos da teoria da diferenciação. Sem diferenciar não há comunicação, porquanto não se distingue o que se comunica do que não se comunica. O ponto é que comunicar envolve sempre o lado marcado e o não marcado, $\mathrm{e}$ ambos compõem a comunicação(LUHMANN, 2006, p. 111, 132). Sistemas observam indica que usamos elementos da teoria dos sistemas como a recursividade para reconhecer que a comunicação contém resultados calculáveis-imprevisíveis, porquanto porta regularidades ao mesmo tempo que mudança, acatar que os sistemas aprendem implica admitir que o direito não está estabelecido em qualquer ente senão no próprio direito, ou seja, que o direito sempre existiu e sempre existirá, porém com formas distintas, com sentidos distintos. A forma e o sentido do direito não são uma resultante controlável, não são um fruto causal de ações e reações, mas uma resultante improvável de comportamentos Eigen, ou seja, de reconhecibilidade das regularidades (FOERSTER, 2003b, p. 321).

Como todos sabem, essa não é a única via de pesquisa com decisão jurídica, é apenas a que aplicamos para pesquisar como é possível o direito aprender consigo mesmo e com seu ambiente. Ninguém, obviamente, é obrigado a considerar que sistema existe, que sociedade é comunicação, que comunicação não é controlável por regras gramaticais nem pelo poder do enunciador ou do enunciado. Porém, partimos do pressuposto de que existem idiomas e que, desde a escrita, os idiomas adquiriram certo grau de 
autonomia de funcionamento e existência. Idiomas nascem e morrem. Idiomas sofrem mutações (palavras e gestos novos são estabelecidos) ao mesmo tempo que seguem como idiomas (regras e normas gramaticais, ethos discursivo etc.). Direito é sistema implica afirmar: direito é idioma, é uma forma de comunicação social, como é a política, a economia, a saúde, a educação, os esportes.

A comunicativação é um aporte teórico e metodológico de pesquisa com e sobre decisão jurídica que se pauta pela transversalidade da teoria dos sistemas com Niklas Luhmann (STAMFORD DA SILVA, 2007, p. 303-346), da linguística com Luiz Antônio Marcuschi e Dominique Maingueneau (STAMFORD DA SILVA, 2010, p. 121-150) e da sociologia, como a etnometodologia (STAMFORD DA SILVA, 2012a, p. 267-316; 2012b, p. 29-58). Numa frase: comunicativação expressa a perspectiva teórico-metodológica que tem a decisão jurídica como operação de observação do sistema jurídico, portanto espaço/tempo do direito, o que nos permite observar como é possível o direito aprender por observação própria.

Com isso, esperamos ter deixado claro o quanto estamos afastados das perspectivas que têm o direito como entidade externa ao social e também como algo controlável por estruturas de poder, por sujeitos; afinal, se direito é comunicação, por mais que haja os detentores de poder político e social, estes não são suficientes para ditar, estabelecer, impor o direito, ainda que possam ter a sensação de assim fazer por um período de tempo. Com isso, evidenciamos o quanto estamos distantes do decisionismo de Carl Schmitt (2007), inclusive porque a teoria dos sistemas de Luhmann nunca apostou no sujeito (individual nem coletivo), o social, tampouco a decisão, antes, em Luhmann, decisão é uma operação de observação e, como tal, é uma operação do sistema mesmo (LUHMANN, 1995, p. 285-298; 2005, p. 415-416; 2006, p. 277-279; 2010, p. 175-177), jamais de uma autoridade, de uma autoridade soberana de maneira que a decisão jurídica só seja justa se aplicação de legislação, negando-se assim qualquer hipótese de haver decisão judicial como creatio ex nihilo (SCHMITT, 2007, p. 74-79). Desavenças entre Luhmann e Habermas à parte, afirmar que a teoria dos sistemas de Luhmann é decisionista aos moldes schmittiano só tem lugar para quem nunca leu uma linha das obras de Luhmann. A evidência do quanto essa acusação se limita ao gueto dos opositores sem leitura está em que a perspectiva de decisão em Luhmann não se volta a um "compromisso entre dedução judicial e vontade judicial" (FISCHER-LESCANO; CHRISTENSEN, 2012, p. 96), afinal, haver texto legislativo não garante uma decisão dedutiva (BELVISI, 2014, p. 355). 
Observar a construção de sentido a partir de dados retirados das decisões catalogadas, saliente-se, não implica ser caçador de sentido, antes se trata de observar o fluxo próprio da construção de sentido jurídico de algo; afinal, sentido tem estrutura ao mesmo tempo que é contingente. No caso do direito - espécie de comunicação social dedicada a tematizar a licitude pautada pela unidade de referência, o código lícito/ilícito -, decisão jurídica é operação de comunicação jurídica e, como operação, diferencia, por observação, ao selecionar e indicar os elementos que integrarão a comunicação que está em pleno momento comunicacional.

Nessa perspectiva, comunicações são constituídas de memória ao mesmo tempo que há dupla contingência do sentido, o que assegura expectativas cognitivas (de aprendizado) e estruturais (normativas) (LUHMANN, 2006, p. 145, 506-511). É que "o enlace de uma comunicação com outras não pode ocorrer arbitrariamente ou ao azar, pois assim a comunicação não seria possível como é” (LUHMANN, 2006, p. 145). Sentido, então, não é uma resultante de conteúdo, uma definição fixada por ideias, tão pouco é infinitamente aberto. Ter sentido é simultaneamente integração entre memória e variação. Sentido envolve mobilidade, mutualidade e coordenação de sentido (LUHMANN, 2006, p. 477-480).

Primeiramente, apresentaremos os elementos da comunicativação, depois seus elementos epistemológicos e, por fim, exporemos a pesquisa sobre a construção de sentido jurídico de bagatela.

\section{Comunicativação como aporte teórico e metodológico}

A comunicativação é o aporte teórico e metodológico transdisciplinar que:

- das reflexões sobre a argumentação jurídica, aportam elementos do debate arbitrariedade/discricionariedade, não para nos filiarmos a um dos lados dessa dicotomia, mas para observarmos, nas decisões, os elementos arbitrários e discricionários; afinal, toda decisão jurídica é constituída de voluntarismo e cognitivismo;

- das reflexões sobre sentido e discurso, aportam elementos como autoria, textualidade, interdiscursividade, limite da interpretação, cenas de enunciação, ethos discursivo, regras do discurso; 
- $\quad$ das reflexões sobre sociedade, aportam elementos como self, mundo da vida, estrutura, agência, reflexividade, comunicação.

Quanto aos elementos de lógica e de epistemologia, a comunicativação se pauta pela lógica do ao mesmo tempo, a lógica circular reflexiva, sem por isso negar situações em que a causalidade e a tautologia têm lugar; afinal, na prática de pesquisa, proferimos afirmações tautológicas (por exemplo, pesquisa é falar a partir de dados) e causais (por exemplo, observando os dados, consideramos $\mathrm{x}$ ). Com isso, apenas alertamos que a circularidade reflexiva não se impõe como única via reflexiva, mais ainda, que aplicar essa lógica não resulta em negar ou eliminar outras lógicas, mas sim resulta em não admitir que há uma única lógica científica aplicável no fazer pesquisa científica. Assim é, porque pesquisa científica envolve escolhas, como o aporte teórico, a qual pode ser concebida como afiliação, quando se pretende proceder à doutrinação, razão porque deixa de fazer ciência e se faz religião, ou como recurso para auxiliar as reflexões quanto às categorias de análise. Por fim, a comunicativação tem por pressuposto epistemológico o pleno afastamento da perspectiva de pesquisa fundamentalista, portanto elementos como objeto, observador e observação são tomados como comunicação, não como entidades físicas ou mentais.

Para esclarecermos o até aqui escrito, consideramos que os seres humanos se comunicam independentemente de haver uma definição única, precisa, determinada de um conceito. Antes, quanto mais determinística for uma definição, menos o conceito comunica algo. Um termo tem sentido não porque porta uma definição cabal, pronta e acabada, mas porque viabiliza a diferenciação entre o que se informa e o que não foi informado, sem eliminar o não informado, mas sim justamente por causa do não informado é que processamos compreensão, entendimento comunicativo. É o que temos por a comunicação ser possível, ainda que improvável; afinal, a inteireza do enunciado é composta de: “1) exauribilidade do objeto e do sentido; 2) projeto de discurso ou vontade de discurso do faltante; 3 ) formas típicas composicionais e de gênero do acabamento" (BAKHTIN, 1986, p. 280-281). A comunicação é possível, ainda que improvável, justamente porque há plausibilidade comunicativa dos meios de comunicação simbolicamente generalizados (LUHMANN, 2006, p. 245-310).

Quanto ao sentido, toda Forma de sentido se desenvolve num meio de sentido (LUHMANN, 2006, p. 36), "todo sentido determinado se refere a si mesmo e ao outro 
distinto" (LUHMANN, 2006, p. 31). Isso implica admitir que o sentido não tem Forma externa a ele, não há fatores externos que dão sentido ao sentido, a construção de Formas no meio de sentido se efetua distinguindo autorreferência de heterorreferência conforme as recursividades atuais (selecionadas) sem por isso eliminar as recursividades possíveis, que seguem potencialmente disponíveis num futuro. Uma das consequências disso é que não pesquisamos vontade, arbítrio, intencionalidade do enunciador, do decididor, mas sim a comunicação mesma, portanto o social jurídico. Pesquisamos a estrutura (regra, memória, fechamento operacional) ao mesmo tempo que a variação (mudança, aprendizado, abertura cognitiva) do direito.

As pesquisas lidam com dados coletados de decisões jurídicas do Judiciário porque acatamos a concepção de os tribunais serem, na modernidade, no Estado de Direito, a organização central da comunicação jurídica, do que implica os tribunais terem o ethos discursivo prevalente na construção de sentido do direito, inclusive em relação à “penetração jurídica na vida cotidiana” (LUHMANN, 2006, p. 387). Não por isso, só de decisão de magistrado vive o direito; afinal, advogado, procurador, promotor também tomam decisões jurídicas, como veremos adiante. Não se trata, portanto, de superioridade dos tribunais, mas de centralidade na perspectiva da dicotomia centro/periferia na construção de sentido. O Judiciário porta uma força, um poder por ser, na modernidade, o centro da comunicação que opera as expectativas cognitivas e normativas do direito, porquanto viabiliza maior diferenciação interna do direito como sistema de comunicação social. Os tribunais constituem a organização social à qual cabe a obrigatoriedade de decidir. O Judiciário tem tal obrigatoriedade, já a periferia (o espaço social, o ambiente do direito) não a tem (LUHMANN, 2006, p. 383-385). Com isso apenas estamos alertando que, quando uma pesquisa não tem decisões de tribunais estaduais ou tribunais superiores - Superior Tribunal de Justiça (STJ), Superior Tribunal do Trabalho (TST), Superior Tribunal Militar (STM), Supremo Tribunal Federal (STF) -, ela é mais frágil quanto às observações e às conclusões por faltarem dados de referência à “estabilidade" do sentido.

Dentre as consequências da transversalidade, temos que a comunicação não tem origem nem fim, porém tem ponto de partida e conclusibilidade. A comunicação humana tem história, memória funcional, estrutura, regras ao mesmo tempo que comporta criatividade, inclusão de ideias, variação e mudança de sentido. Comunicação forma expectativas que fixam (selecionam) um futuro indeterminado; afinal, a varia- 
ção comunicativa não se produz arbitrariamente (pelo interesse, pela intencionalidade, pela consciência, pela vontade de um sujeito concreto), mas sim de maneira altamente seletiva (LUHMANN, 2006, p. 40). A comunicação humana, ao mesmo tempo que fixa sentido construindo identidade, muda o sentido por conta da "dimensão temporal que impede a petrificação objetivamente coisificada da dimensão social” (LUHMANN, 2006, p. 35). Noutras palavras, "comunicação é o auto-comportamento de um sistema operacional recursivo que é duplamente fechado em si mesmo" (FOERSTER, 2003b, p. 322). Ou ainda, é a autopoiesis da comunicação que "expressa um momento criativo (poiesis) e um momento limitado (estrutura)" (MASCAREÑO, 2007, p. 207). Ou também, na análise morfogenética, o social é a conflação do dualismo analítico estrutura/ agência, porquanto a comunicação humana tem esses dois níveis analíticos como inseparáveis (ARCHER, 2009, p. 125-126).

Outra consequência é que texto e autoria não representam uma relação criação/ criador. Discurso é uma organização atravessada por regras (coletivo, normatividade) ao mesmo tempo que é assumido (individualidade, mas não como personalização e sim como ethos discursivo). Não há comunicação sem comunicador, porém não há autor do ar, da chuva, ainda que haja a referência ao autor de um texto (escrito ou oral), porém o texto é dominado pelo dispositivo de comunicação do qual ele mesmo provém (MAINGUENEAU, 2015, p. 27). Essa mesma perspectiva encontramos na teoria social de Luhmann $(1996$, p. 20) quanto ao acoplamento entre o psíquico e o social: "a percepção mesma não é comunicável, só a comunicação é comunicável”. O ser humano individuado, concreto é referenciado numa comunicação como um meio para a compreensão em situações nas quais se quer atribuir a alguém uma responsabilidade, uma opinião, uma visão de mundo, uma verdade, porém o que pode conhecer é o que foi comunicado, não a consciência, a subjetividade, mas sim a intersubjetividade comunicativa. A comunicação, quando se refere à percepção, não está referida à consciência ou a qualquer outro elemento constitutivo do ser humano como subconsciente individual. Trata-se da rede recursiva de comunicações que a comunicação mesma faz possível (LUHMANN, 1996, p. 20). Não é, portanto, o sujeito que cria, determina o discurso, a comunicação, a sociedade, tão pouco o sujeito é assujeitado, como se as regras que regem o discurso, a comunicação, o social condicionassem sua posição discursiva à formação discursiva e ideológica (POSSENTI, 1998, p. 95-107; 2009, p. 81-90; MAINGUENEAU, 2010, 2015). Com isso nos afastamos da dicotomia indi- 
vidualismo/coletivismo presente na teoria social; afinal, autoria não se confunde com ser criador do discurso, mas sim que o sujeito assume o discurso, sendo um enunciado ao mesmo tempo que um ato de fala, um discurso, portanto, coletivo, social humano. Não há criador de idiomas. Um idioma é coletividade ao mesmo tempo que cada falante tem sua individualidade em sua fala, o tom de voz, a maneira de se expressar, uma identidade individual.

Uma comunicação tem seus limites estabelecidos não por haver uma natureza referente, uma consciência referente, um objeto referente, mas por haver sua própria rede recursiva de sentido, ou seja, por a comunicação mesma ter evoluído ao ponto de construir elementos internos que lhe permite organizar sua própria capacidade de conexão com informações, enunciados, gestos, falas, textos. Ocorre que "a sociedade como sistema de comunicação se acopla aos processos de consciência dos indivíduos” (LUHMANN, 1996, p. 27). Com isso, afirmar que sociedade é sistema de comunicação e não consciências não implica descartar os seres humanos, mas sim ter a autoria como referente comunicativo, inclusive quanto ao ethos do discurso, o qual não se confunde com a ética de um sujeito empírico (POSSENTI, 1998, p. 97; 2001, 2002; MAINGUENEAU, 2016, p. 13-32).

Quanto ao efeito discursivo, não tem a mesma força nem o mesmo sentido uma afirmação de uma criança e uma proferida por um adulto. À semelhança, um enunciado de um ministro do STF não tem o mesmo efeito discursivo, inclusive no direito, de um proferido por um juiz de primeiro grau, ou por um advogado, um promotor, um procurador, um delegado etc. Do embate entre linguagem natural ou formal, entre inatismo ou convencional, temos a questão de as línguas serem ou não códigos (POSSENTI, 2001, p. 6-27), bem como a questão dos nomes serem representações da realidade ou usos convencionais humanos, esses embates conduzem à distinção entre verdade por correspondência, verdade por coerência ou verdade pragmática, aquela que se dá por convenção, devido ao uso de determinada denominação (RORTY, 2005). Há ainda o embate quanto a ser o indivíduo (falante/ouvinte) quem estabelece o sentido ou se o sentido é um produto da coletividade social humana (HABERMAS, 2002, p. 16-62). Referimo-nos aqui ao fato de que a força, o efeito discursivo de uma afirmação, não é ignorada na análise dos dados, porém isso não implica que há autoria como criadora de sentido. Aproveito para esclarecer que afirmar que decisão jurídica é constructo social não se confunde com o construtivismo radical. Decisão jurídica não é o que o julgador 
quiser. Decisão jurídica é comunicação e, com tal, não tem dono, não tem autoria, não tem criador, ainda que tenha ser humano referenciado, a exemplo, o ministro " $A$ " votou " $z$ ". Texto (falado, escrito, gesto) é discurso como "substantivo contável que pode se referir a acontecimentos de fala” (MAINGUENEAU, 2015, p. 23).

Não pesquisamos intenção, desejo, necessidade, vontade. Pesquisar comunicação implica lidar com a perspectiva de sujeito discursivo e não criador do discurso, implica lidar com a comunicação. Com o social que toma o ser humano como um composto de elementos físicos (corpo), biológicos (células), psíquicos (mente, consciência), sociais (comunicação) (SOUTO; SOUTO, 2003, p. 175-176; LUHMANN, 1996, p. 15; ARCHER, 2009, p. 100-101). Assim, sujeito não é a origem do sentido, da linguagem, do idioma, da história, da sociedade (POSSENTI, 2009, p. 82), os “sujeitos não estão na origem dos discursos” (POSSENTI, 2009, p. 83), ainda que haja o falante; afinal, não há discurso, comunicação, sociedade sem ser humano, todavia, tão pouco há discurso, comunicação, sociedade de um só. Um monólogo, inclusive, para ser discurso, comunicação, sociedade, requer ouvinte, portanto, partilha. Partilha implica pôr à disposição informações; afinal, ao informar não já se estabelece comunicação, não se impõe uma compreensão, nem quando se impõe uma submissão. "A sociedade não pode ser pensada sem comunicação, assim como a comunicação não pode ser pensada sem sociedade” (LUHMANN, 2006, p. 3). Essa dupla implicação é contingente, sempre poderia ser diferente de como foi.

Esperamos ter deixado claro que nossas pesquisas não se ocupam em caçar, nem em cassar sentido, mas, sim, observar o aprendizado do direito, ou seja, a sua própria construção de sentido. Observar o processo de atalhamento da compreensão. Observar a recursividade da comunicação jurídica.

Numa conversa se pressupõe, conscientemente ou não, que as pessoas compreendem o que ouvem porque vivemos uma "gramática” básica; afinal, analfabetos ou não, todos dominam elementos do idioma usado para comunicar algo. Ao pedir a um garçom, “Por favor, me dê uma água”, não se tem por expectativa uma reação como “Como assim 'me dê'? Aqui é um restaurante, não um estabelecimento de doação”. Não se exige a formulação: “Por favor, me traga água”. Cotidianamente, o garçom vai buscar e põe na mesa uma garrafa de água com copos. Esse fenômeno é o que a fenomenologia chama de regularidades do mundo da vida (Lebenswelt) (HUSSERL, 2006, p. 57-58), são “esquemas primários” (GOFFMAN, 2012, p. 45), ou ainda, pro- 
priedades racionais de expressões de indexação e outras ações de práticas contínuas e contingentes organizadas na vida cotidiana, são "práticas 'reflexivas”, "atividades familiares comuns", práticas "reconhecidas como "uma outra primeira vez" (GARFINKEL, 2018, p. 9); “consenso atemático do mundo da vida” (LUHMANN, 2006, p. 4), o que na linguística se chama de princípio da economia comunicacional $(\mathrm{KOCH}$, 2006, p. 30-31), bem como Spencer-Brown (1969, p. 43) chama de princípio da relevância (principle of relevance), o qual consiste em que, "se uma propriedade é comum para toda indicação, ela não precisa ser indicada”. A comunicação, resumidamente, envolve autorreferência e heterorreferência, portanto é dotada de recursividade da forma na forma e de re-entry, heterorreferência do meio na forma (KAUFFMAN, 1987, p. 56).

Resumimos a referida transversalidade na frase: comunicação é a célula da sociedade. Sociedade é estrutura ao mesmo tempo que é agência (como no realismo crítico de Margareth Archer (2009), comunicação/sociedade é sistema ao mesmo tempo que é ambiente (como na teoria da sociedade de Niklas Luhmann). Discurso, sociedade, social, sistema social, comunicação soam sinônimos; afinal, são constructos sociais em interdiscurso num contexto determinado. Discurso, sociedade, sistema social, comunicação são constructos (construção, desconstrução, reconstrução). São mutantes, contingentes, podem ser diferentes do que são, de como foram anunciados. Contudo, não são manipuláveis aleatoriamente, não há idioma de um indivíduo só. Por mais que passível de manipulação que sejam os discursos, a sociedade, os sistemas sociais, e a comunicação, são possíveis devido a limites temporais, espaciais, psíquicos e sociais. Por mais que haja idiossincrasia, não há comunicação de um só indivíduo.

Como resumo do aporte teórico, elaboramos a circularidade recursiva apresentada a seguir (Figura 1), à qual recorremos ao observarmos a construção de sentido do direito via decisão jurídica. Por se tratar de uma aplicação recursiva, a leitura remeterá o leitor a voltar no diagrama a cada continuidade na leitura. A leitura deve se dar da seguinte maneira: "comunicação é a célula da sociedade"; "sociedade é sistema de sentido", "sentido é distinção", distinção é perfect continence, sem se proceder a uma distinção (perfect continence) não há comunicação. Neste ponto, o leitor é remetido de volta à primeira frase: “comunicação é a célula da sociedade” e, desta, já não precisa reler tudo, mas seguir diretamente à frase "sentido é produto de operações do sistema" e desta seguir na leitura. 


\section{FIGURA 1 - DIAGRAMA CIRCULAR REFLEXIVO}

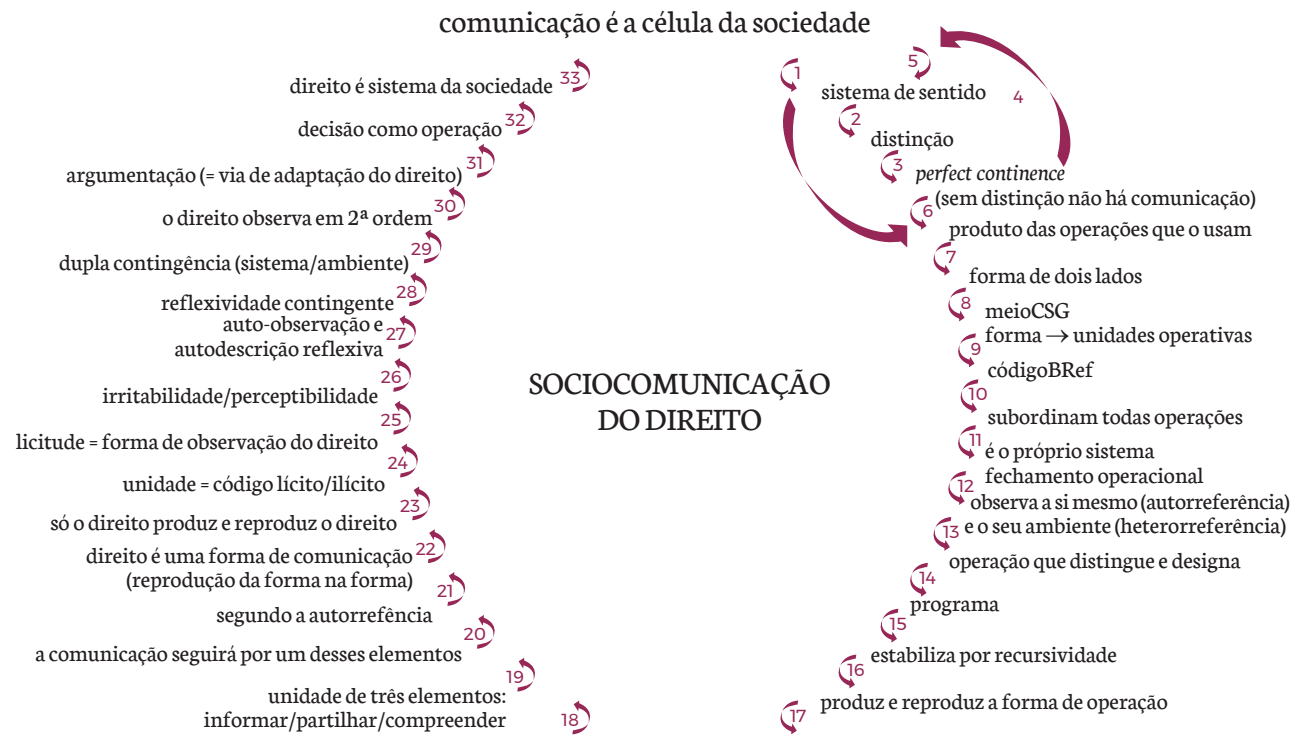

a forma de operação que produz e reproduz

o sistema da sociedade é a comunicação

\footnotetext{
${ }^{* 1}$ Dualidade constitutiva $=$ forma de dois lados implica que os dois lados integram a Forma $=$ meio $/$ forma sistema $/$ ambiente $=$ para haver um lado tem de haver necessariamente o outro.

${ }^{* 2}$ MeioCSG = meio de comunicação simbolicamente generalizado.

${ }^{* 3}$ Forma $=$ CódigoBR $=$ código binário de referência $=$ é unidade ambivalente de sentido cujos lados são conforme/não conforme ao sentido da comunicação atual.

${ }^{*}$ Códigos subordinam todas as operações (fechamento estrutural) ao mesmo tempo que deixam em aberto a fonte de validez (abertura cognitiva).

*5 Não é o código que determina o valor a ser designado, se conforme ou não conforme, o código é pré-requisito, condição para a possibilidade das condições que regulam qual de seus valores se aplicará adequadamente na comunicação atual. A designação do valor da operação, a direcionalidade semântica a operar numa comunicação depende das instruções que indiquem se e como os valores do código são atribuídos correta ou incorretamente, ou seja, dos programas. Programas são diretrizes, instruções, princípios, nortes, "direcionalidade semântica" (Ausrichtung der konditionierenden Semantik)(Luhmann, 2006, p. 251). A página 251 corresponde à p. 192, no livro Das Recht der Gesellschaft).

*6 Designa $=$ Bezeichnung $=$ designa, aponta, seleciona, nomeia o programa $=$ semântica adicional que instrui a seleção do valor na comunicação atual.

${ }^{* 7}$ O programa estabiliza a produção de sentido instruindo recursivamente o valor do código a ser empregado.

${ }^{* 8}$ Recursividade produz e reproduz a forma de operação que conserva (estrutura) e produz (variação) do sentido.

*9 É como é, mas poderia ter sido de outra maneira (dupla contingência - ambiente/sistema).

FONTE: ELABORADO PELO AUTOR.
}

Considerando o diagrama, observe, leitor, que as setas estão em formato de circularidade. Assim as desenhamos como referência à circularidade reflexiva, portanto à recursividade. Pesquisar a construção de sentido do direito por meio de decisão jurídica implica pesquisar comunicação, não objeto. Ocorre que pesquisar é observar, portanto 
operar uma distinção (perfect continence); afinal, sem promover distinção não há expressão, não há compreensão, não há comunicação.

Com esses pressupostos, voltamos ao início para então seguir rumo ao sentido. Com isso, aplicamos mais uma recursividade. Sentido é produto das operações que o usam, assim, é forma de dois lados. No caso da comunicação como forma de dois lados, ela mesma contém o meio de sentido e a forma de sentido; afinal, para uma forma de sentido existir, ela requer um meio de sentido no qual possa se constituir. Porém, algumas formas de comunicação humana desenvolveram hipercomplexidade, e, nesses casos, temos os sistemas sociais de comunicação. Cada sistema se diferencia por conter uma unidade de referência. No caso do direito, ele é o sistema que tem por unidade a forma de sentido dedicada às comunicações sobre licitude. A unidade é o código binário de referência lícito/ilícito, que, como tal, subordina todas as operações do direito ao mesmo tempo que deixa em aberto a fonte de validez, ou seja, o valor a ser atribuído numa comunicação; afinal, só o direito comunica o que é lícito (conforme ao direito) e o que não é conforme ao direito (ilícito):

[...] o valor positivo é aplicado quando uma temática (Sachverhalt) está em conformidade com os padrões do sistema. O valor negativo é aplicado quando uma temática viola os padrões do sistema. $\mathrm{O}$ que acabamos de chamar de "temática" é construído pelo próprio sistema. O sistema não reconhece uma entidade externa que possa prescrever o queé temática para o sistema mesmo, embora esse termo possa se referir a circunstâncias internas e externas do sistema (LUHMANN, 2006, p. 236).

Um caso jurídico é tomado como uma comunicação no direito e, como tal, o direito irá operá-la (observar) para decidir o que será tomado por lícito e o que será ilícito. Essa operação implica o direito observar a si mesmo ao mesmo tempo que observa seu ambiente: trata-se da autorreferência e da heterorreferência. Para decidir que valor será apontado, designado, o direito recorre a seus programas, estabelecendo, por recursividade (memória e variação), como irá produzir e reproduzir sua forma de operação, ou seja, a atribuição de valor lícito ou ilícito quanto à comunicação que o está pondo em operação. Chegamos, assim, à circularidade.

Voltando ao nosso gráfico, comunicação é constituída de três elementos: informar, partilhar e compreender. A comunicação mesma é quem irá decidir por qual desses elementos ela seguirá operando (autorreferência comunicativa). No caso do direito, só o direito pode operar comunicações sobre licitude; portanto, é o direito 
mesmo que irá atribuir o valor lícito ou ilícito à comunicação atual, aquele que o está irritando a se comunicar. É o que temos com a auto-observação e autodescrição seletiva do direito no direito, o qual processa comunicativamente por meio de reflexividade contingente, ou seja, sempre pode operar de maneira diversa da que está operando, comunicando, decidindo.

A distinção meio/forma é usada para desenvolver a perspectiva de sentido utilizada na pesquisa. No caso do direito - sistema de comunicação da sociedade pautado pelo código binário de referência lícito/ilícito, cuja unidade de referência o distingue das demais formas de comunicação da sociedade, dos demais sistemas sociais -, o estabelecimento de quando uma comunicação enlaça o lado lícito ou o ilícito não se dá via o código, mas sim via o programa, "regras de decisão [...] servem para especificar os pontos de vista da seleção” (LUHMANN, 2005, p. 379). A semântica adicional que detém instruções de como valorar algo como pertencente/não pertencente (zugehörig/ nichtzugehörig) ao sistema não se dá por causa do código.

A Figura 1 se limitou ao direito, por ser este o sistema de referência central de nossas pesquisas; afinal, são pesquisa sobre a construção de sentido do direito via decisão jurídica, o que nos leva a explorar a concepção de sentido, argumentação na teoria dos sistemas, bem como na linguística, em especial na análise de discurso. Porém se pode empregar a terminologia a qualquer área de conhecimento; afinal, sistema é sistema de sentido, é forma de comunicação hipercomplexa ou ainda comunicação funcionalmente diferenciada porque atada a uma temática. Na perspectiva sistêmica, nenhuma comunicação se estabelece sem que ocorra uma diferenciação (perfect continence, como na teoria da forma de George Spencer-Brown $(1969$, p. 1)), teoria que, vinculada à teoria da incompletude de Kurt Gödel, leva Luhmann à ideia de que não há início nem término de uma comunicação humana, há seleção e diferenciação, o que envolve um repertório (estrutura) de sentido ao mesmo tempo que a infinita possibilidade de inclusão de elementos numa conversa, é, pois, infinito o caminho pelo qual uma conversa pode seguir.

\section{A pauta epistemológica}

A depender da pesquisa, as decisões jurídicas são catalogadas em sites de tribunais, em redes sociais, em documentos, no fórum. Predomina a técnica documental, seguida da observação não participativa, porém é possível obter dados por meio de entrevistas e questionários. Uma vez com os dados, eles são organizados e analisados. Utilizamos 
planilha de Excel para organizar os dados, o que poderia ser feito com qualquer outro software que faça cálculos e produza gráficos de coluna, de linha, pizzas, dispersão, historiograma, de caixa, dinâmicos. As análises são qualitativa e/ou quantitativa dos dados, podendo predominar uma ou outra, como ocorre muitas vezes que a pesquisa está dedicada a analisar argumentação ou discurso. A definição de que gráfico utilizar, se fazer análise quantitativa, qualitativa ou quali-quanti depende dos objetivos da pesquisa e das questões de pesquisa.

A pauta epistemológica tem por referência central a dicotomia objeto/sujeito, da qual nos afastamos com a tríade observador/observado/observação, cuja integração nos afasta de dicotomias como verdade/justificação, certeza/crença, representação/ antirrepresentação, portanto da hipótese de haver elementos externos à cientificidade, a exemplo da hipótese de ditames de divindades, de natureza humana ou qualquer outro ente sobrenatural. Comunicação humana é construção evolutiva de comunicação humana; afinal, a escrita não se deu aleatoriamente ou por revelação divina, a imprensa não adveio de uma revelação divina, antes, são desenvolvimentos históricos da evolução comunicacional humana mesma. A demarcação da ciência - a distinção entre um conhecimento e um não científico - não está em haver um objeto e o método científico, mas sim na distinção entre postura fundamentalista e antifundamentalista, ou seja, entre proselitismo, doutrinação, ortodoxia em oposição à circularidade reflexiva, gödelização da racionalidade, lógica do ao-mesmo-tempo.

Na pauta teórica, lidamos com os elementos que compõem a perspectiva teórica das pesquisas, lá enfatizamos a questão da autoria. Aqui, aplicando a epistemologia antifundamentalista, temos que, como constructo, a decisão jurídica não é pré-dada, predita, preestabelecida, não pesquisamos a origem, as causas, mas sim comunicações, entendidas como ato constituído das operações de informar (enunciado), partilhar (expressão, dar-a-conhecer, ato de participar da comunicação) e compreender (entendimento, mudança do estado não comunicativo ao comunicativo). Salientamos que a compreensão não é um acordo comunicativo, afinal compreendemos mesmo quando discordamos completamente do que o outro enuncia, assim, compreender pode ser consenso tanto quanto dissenso, só não pode ser não comunicação(LUHMANN, 1996, p. 23; 2005, p. 79, 91, 309; LUHMANN, 2006, p. 49-53; LUHMANN, 2010, p. 65). Assim como discurso tem unidades transfrásticas (encadeamento de frases) e, por isso, é submetido a regras de organização, como ato que modifica uma situação (ato de fala), portanto interativo, contextualizado, e assumido por um sujeito, como fonte de referência 
pessoal, temporal e espacial; afinal, “a fala é dominada pelo dispositivo da comunicação do qual ela provém” (MAINGUENEAU, 2015, p. 27).

Nesses termos, decisão jurídica contém estrutura ao mesmo tempo que contingência. Há enunciador, porém isso não torna esse enunciador detentor do controle, ditador das regras da comunicação, do discurso, antes, essas as regras, as normas são constructos sociais. A concepção de comunicação empregada nas pesquisas está pautada pela teoria da sociedade de Niklas Luhmann apenas porque desconhecemos outro sociólogo do direito que tenha partido da gödelização da racionalidade, da Forma de dois lados de Spencer-Brown, da teoria dos sistemas que observam de Heinz von Foerster e da teoria da comunicação da cibernética para lidar com o direito. A relação dessa concepção com as da linguística como trabalho social de Luiz Antônio Marcuschi e da análise de discurso de Dominique Maingueneau deu às pesquisas observações não possíveis via elementos da hermenêutica jurídica ou de exclusiva análise de discurso, por exemplo.

A reação mais comum a essa perspectiva é considerar que ela é relativista extremista, que promove um "vale-tudo" e que desconsidera o ser humano como ator, falante, ouvinte, decididor. A acusação de relativismo implica que a teoria serve para tudo, portanto pode ser aplicada para defesa da violência extrema tanto quanto para o pacifismo extremo. Essa acusação é compreensível; afinal, a perspectiva teórica em si não basta para eliminar a defesa de ideias; afinal, teoria científica é uma ideia humana. Com a epistemologia temos o reconhecimento que nem todo conhecimento é científico. Aqui está nossa limitação. Estamos limitados ao científico e o afastamos plenamente do conhecimento religioso, por exemplo. Tratamos de comunicação humana e, como tal, não é possível sem seres humanos. Voltemos a lembrar: não é o falante e/ou o ouvinte que determina, estabelece, controla o que se diz e o que se ouve, é a comunicação quem faz isso. Essa distinção esclarece o quanto não observamos tomada de decisão de atores sociais, nem papéis sociais específicos, mas sim como são possíveis as comunicações jurídicas, ou seja, como as operações de informar, partilhar e compreender (Information/Mitteilung/Verstehen) viabilizam o direito ser como ele é, o direito ter e se dar em construção de sentido no direito. Não observamos, portanto, intenções, mentes, consciências, desejos, vontades, gostos, mas comunicação, essa unidade das diferentes operações de informar, partilhar e compreender. Deixo ao leitor sua leitura da seguinte passagem: “Toda comunicação deve ao mesmo tempo comunicar que é uma comunicação, e deve marcar quem comunicou o quê, para que a comunicação seguinte possa ser 
determinada e a autopoiesis possa continuar” (LUHMANN, 2006, p. 61)1. Esse debate nos leva ao paradoxo da diferenciação, ou seja, da observação como assinalar e distinguir. Nessa perspectiva, não cabe falar em coisa em si ou algo semelhante, mas sim que a diferenciação ocorre com a observação, não antes, nem depois dela, inclusive quando não se trata de "ontologia autoral” (MAINGUENEAU, 2010, p. 33), antes se toma discurso não como "um território circunscrito, mas como um espaço incerto entre dois maciços, lá onde se desfazem os laços aparentemente tão fortes entre as palavras e as coisas, entre a linguagem e o mundo" (MAINGUENEAU, 2015, p. 31).

As questões consequentes da relação objeto/sujeito, de o sujeito ser autor, criador do discurso (da comunicação) são afastadas quando se parte da diferenciação, do paradoxo da diferenciação, pois distinguir não resulta em apartar, separar, mas em diferenciar. Assim, por exemplo, direito se distingue sem por isso se isolar da economia, da política, da religião, da psiquê humana; afinal, só há identidade na diferença, posto que diferença é perfect continence, como já nos referimos à ideia de Spencer-Brown, na perspectiva da comunicação isso implica que não há comunicação sem que se promova uma distinção. Distinguir implica assinalar e diferenciar, portanto toda Forma só é possível num meio. No caso da comunicação humana, toda Forma de sentido só é possível num meio de sentido.

Aplicando a distinção meio/Forma à teoria da sociedade, temos que discurso, comunicação contém simultaneamente um ambiente (contexto, cenas de enunciação) e uma organização (forma, sentido, regras, organização). No caso do direito, temos que uma comunicação jurídica se diferencia de todas as outras comunicações humanas porque tem um meio e uma forma específica, contudo não há direito sem a política, a economia, a religião, a psiquê humana etc., porém direito não é, não se confunde com política, economia, religião, psiquê humana etc. O sentido, nessa perspectiva, contém um meio e uma forma, portanto o paradoxo do sentido é que o sentido contém uma memória ao mesmo tempo que se atualiza cada vez que é utilizado e segue em potência, assim, há o sentido atual e o potencial. Num debate jurídico, o sentido do direito em debate é atual-momentâneo e possível-em-aberto, por isso falamos em construção de

1 Em espanhol: “Cada comunicación debe comunicar al mismo tiempo que ella misma es una comunicación y debe hacer énfasis en quién y qué es lo que se ha dado a conocer, para que pueda determinarse la comunicación de enlace y para que la autopoiesis pueda continuar" (p. 61). Em inglês: "Every communication must at the same time communicate that it is a communication and mark who has uttered what so that follow-up communication can be determined and autopoiesis continued" (Luhmann, Society as social system, p. 45). Em alemão: "Jede Kommunikation muß zugleich kommunizieren, daß sie eine Kommunikation ist, und sie muß markieren, wer was mitgeteilt hat, damit die Anschlußkommunikation bestimmt werden kann" (Luhmann, Die Gesellschaft der Gesellschaft, p. 86). 
sentido do direito como essa constante potencialidade de mudança ao mesmo tempo que há memória, é o que temos com a re-entry da Forma na Forma (SPENCER-BROWN, 1969, p. 56), com a “order from noise” (FOERSTER, 2003a, p. 11), com o paradoxo do sentido, pois "o significado se torna um meio continuamente autorregenerativo para a seleção contínua de formas específicas”2 (LUHMANN, 2006, p. 39). Sendo o direito uma das espécies de comunicação humana hipercomplexa, sistema de comunicação social humana que é, como sistema, o direito observa a si mesmo e o seu ambiente (seu diferente, seu exterior). Saliente-se que, sendo auto-organizado, o direito não apenas se alimenta de ordem, mas também de ruídos ${ }^{3}$ (FOERSTER, 2003a, p. 11).

O direito, nessa perspectiva, muda, se altera mesmo quando permanece, pois o reafirmar um mesmo entendimento sobre algo promove a constante adaptação ao social. A variação e seleção não se dão arbitrariamente, mas de maneira altamente seletiva, pois o problema do tempo, da preservação, da capacidade de ampliar o número de pressupostos pelos quais ele, o direito, como ordem social, se pauta envolve opiniões, posições, expectativas, ordens mais ou menos esperadas (LUHMANN, 2006, p. 328). Ocorre que, paradoxalmente, "se uma comunicação significativa se torna possível, há a mesma probabilidade para que qualquer comunicação específica, a qualquer momento, torne-se improvável” (LUHMANN, 2006, p. 328). Isso leva à questão de “como é possível algumas estruturas carregadas cada vez mais de pressupostos - ou seja, cada vez mais improváveis - surjam e funcionem com normais"? (LUHMANN, 2006, p. 326). Trata-se do paradoxo da evolução, da preservação via mudança, o que se dá na comunicação humana, como se pode verificar com a evolução do modo humano de se comunicar (escritura, imprensa, internet). Aplicando isso ao direito, Forma de comunicação humana que é, temos que ele se deixa ser estimulado à mudança justamente para se preservar; afinal, em toda comunicação ocorrem simultaneamente estados diferentes, inquietações, as quais são constantemente “aquietadas" e voltam a se “inquietar” viabilizando assim uma comunicação provável (LUHMANN, 2006, p. 325). Ou família, por exemplo, porta o mesmo sentido jurídico ao longo dos anos?

Nessa perspectiva epistêmica, decisão jurídica é o espaço/tempo de o direito viver as constantes oportunidades de, a cada decisão, selecionar em que se manter e em que

2 No original: "wird Sinn zu einem sich selbst laufend regenerierenden Medium für die laufende Selektion bestimmter Formen” (LUHMANN, 1997, p. 58).

3 A frase original, da qual retirei a paráfrase, pois a reprodução ipsis litteris não seria suficiente é: “Thus, in my restaurant self-organizing systems do not only feed upon order, they will also find noise on the menu". 
se alterar, não se trata de objeto/sujeito, como se uma questão de interpretação leitura do ser externo, mas da decisão como operação de sentido do direito. Cada decisão é uma novidade, mesmo aquela que reforça o sentido da decisão anterior; afinal, mesmo ao reforçar o entendimento anterior sobre algo e, assim, mantendo a expectativa de decisão, o direito informa que está mantendo a decisão anterior, e essa informação é uma nova informação do direito para o direito, para a sociedade. Com isso, o Judiciário não é criador, autor do direito, ainda que ele seja a organização central do sistema jurídico, afinal, “a organização da jurisdição seria aquele sistema parcial (subsistema) no qual o sistema do direito tem seu centro” (LUHMANN, 2005, p. 383).

Para fins de nossas pesquisas, um conselho de um advogado, uma petição contém decisões jurídicas, assim como movimentos sociais também tomam decisões (expressam, partilham de informações) jurídicas. Assim, ainda que os tribunais sejam centro da comunicação jurídica, não só de Estado (legislação e Judiciário) que vive o direito. Isso nos levou à distinção decisão-jurídica/decisão-judicial/decisão-judiciária (STAMFORD DA SILVA 2012b, p. 50).

Para demonstrar como desenvolvemos pesquisas dedicadas a observar a construção de sentido do direito, apresentaremos a pesquisa sobre a construção do sentido de bagatela, do princípio da insignificância no direito.

\section{A construção de sentido de bagatela}

Para pesquisar a construção de sentido jurídico de bagatela, ou princípio da insignificância, coletamos decisões nos sites dos 27 estados, do STJ e do STF, obtendo por universo amostral de 28.802 decisões como resultado da busca com o termo bagatela e 162.455 decisões como resultado da busca com o termo insignificância e a expressão princípio da insignificância. Para estabelecer a população, recorremos à seguinte fórmula:

$$
\frac{\frac{z^{2} \times p(1-p)}{e^{2}}}{1+\left(\frac{z^{2} \times p(1-p)}{e^{2} N}\right)} \mathrm{N}=
$$

$\mathrm{N}$ = tamanho da população

$\mathrm{e}=$ margem de erro (porcentagem no formato decimal)

$\mathrm{z}=$ escore $\mathrm{z}$

O escore z é o número de desvios padrão entre determinada proporção e a média. 
Para um nível de confiança de $95 \%$ e margem de erro de $3 \%$, resultado obtido via https://www.solvis.com.br/calculos-de-amostragem/, a população estabelecida para a pesquisa consistiu nas 30 decisões mais antigas, todas as 131 decisões do STF e as 121 do STJ, bem como 2.115 decisões dos tribunais estaduais, escolhidas aleatoriamente, considerando como critério a necessidade de haver ao menos uma de cada ano disponível.

Para definir quais decisões dos estados analisar, consideramos o percentual representativo por estado, bem como que deveria haver decisões do máximo de anos possíveis. Por exemplo: Acre (AC), Amapá (AP) e Maranhão (MA). Na Tabela 1, na linha superior constam os anos, de 2000 a 2019, com a casa decimal, de 00 a 19. Na linha abaixo, o quantitativo de decisões por ano.

\section{- TABELA $1 \cdot$ QUANTITATIVO DE DECISÕES POR ESTADO}

\begin{tabular}{c|c|c|c|c|c|c|c|c|c|c|c|c|c|c|c|c|c|c|c|c} 
& 00 & 01 & 02 & 03 & 04 & 05 & 06 & 07 & 08 & 09 & 10 & 11 & 12 & 13 & 14 & 15 & 16 & 17 & 18 & 19 \\
$\mathrm{AC}$ & 1 & 1 & 0 & 0 & 0 & 2 & 2 & 3 & 5 & 4 & 5 & 7 & 9 & 11 & 14 & 28 & 36 & 56 & 23 & 19 \\
$\mathrm{AP}$ & & & & & & & & & & & 1 & 3 & 5 & 2 & 3 & 1 & 1 & 3 & 3 & 1 \\
\hline MA & & & & & & & & & & & & & & & & & 8 & 61 & 43 & 14 \\
\hline
\end{tabular}

FONTE: ELABORADA PELO AUTOR.

Das 226 decisões do Acre, coletamos as de 2000 e 2001, duas de 2005 a 2010, três de 2011 a 2014 e cinco de 2015 a 2019, perfazendo o total de 53 decisões.

Coletamos todas as 20 decisões do Amapá (AP).

Das 126 decisões do Maranhão (MA), coletamos cinco decisões de 2016 e dez de 2017 a 2019. Perfazendo o total de 35 decisões.

Esse mesmo procedimento foi aplicado para todos os estados.

Para estabelecer quais decisões analisar, recorremos ao website https://www.4devs. com.br/gerador_de_numeros_aleatorios. Lançamos a quantidade de decisão por estado. Com o quadro de números aleatórios, acessamos o site e catalogamos aquelas correspondentes à entrada do número definido pelo gerador de números aleatórios.

Procedemos à análise quantitativa e qualitativamente para observar como foi possível a ideia de bagatela integrar o direito brasileiro. Estabelecemos como variáveis: o processo, o ano, a turma, o relator, a tipicidade jurídica (tipo = classificação jurídica, como família, execução fiscal, peculato, furto, roubo, trânsito, violência doméstica), o elemento fático, a decisão (atribuindo 1 para decisão que aceita o argumento da baga- 
tela, 0 quando nega e ø quando rejeita mas reduz a pena ou a decisão traz um benefício ao acusado, argumento doutrinário, legislativo e jurisprudencial, por fim, observações.

QUADRO 1 VARIÁVEIS DA PESQUISA

\begin{tabular}{l|l|l|l|l|l|l|l|l|l|l} 
Processo & Ano & Turma & Relator & Tipo & Fato & Decisão & Doutrina & Legislação & Jurisprudência & OBS. \\
\hline
\end{tabular}

FONTE: ELABORADO PELO AUTOR.

Dados catalogados do inteiro teor das decisões, observamos a construção do sentido de direito, "o processo de construção de regras que toma uma forma autopoiética que se nutre de si mesma” (LUHMANN, 2005, p. 263).

O método consistiu em ler e reler as decisões identificando o(s) enunciado(s) mais presente (repetido), e, nesse processo, localizamos as intertextualidades de decisões, a doutrina e a legislação. As decisões mais antigas nos serviram para localizar como foi sendo construído o sentido de bagatela no direito brasileiro.

À medida que fomos desenvolvendo a pesquisa, observamos que decisões eram desnecessárias por trazer insignificância não quanto à bagatela, mas a outro debate. Outras sequer apareciam na busca, porém eram muito citadas nas decisões analisadas, por isso passaram a integrar os corpora da pesquisa.

Para pesquisar a construção do sentido de bagatela, não nos ocupamos em localizar o sentido de bagatela desenvolvido nas decisões jurídicas, observamos como foi possível o tema ingressar no sistema do direito, que elementos do sistema foram manipulados na irritação do sistema? Ou ainda que argumentos foram manipulados na sua aceitação e negação? Quais decisões foram mais referenciadas por outras, ou seja, que decisões deram forma à memória do sentido de bagatela? Como argumentos aceitos foram alterados? Como é possível que um mesmo tribunal tome decisões opostas? Observamos como o sentido vivencia sua construção, sua formação/reformulação/ deformação/formação e assim segue ciclicamente em constante construção; afinal, a comunicação nunca para.

Iniciemos com a problematização "como foi possível a bagatela ser tema do direito”, uma vez que não havia legislação nem jurisprudência. O debate teve início em embates doutrinários. As observações das decisões nos levam a afirmar que bagatela se fez tema jurídico por irritação da doutrina, portanto irritação do sistema científico ao sistema jurídico. Nas decisões mais antigas, só há citações de textos doutrinários, não 
há de decisões anteriores nem de textos legislativos. Ainda que predomine, o tema não se restringe ao direito penal, há decisões envolvendo temas dos direitos civil, tributário, administrativo.

Observando as decisões, localizamos os argumentos que constituíam a construção de sentido de bagatela, como se pode verificar no Quadro 2.

- QUADRO $2 \cdot$ CONSTRUÇÃo DE SENTIDO DE BAGATELA

\begin{tabular}{|c|c|c|}
\hline Ano & Tribunal & Argumento \\
\hline 1979 & STF & Política criminal + lesividade social \\
\hline 1981 & TJSC & Delito formal e material + bem jurídico protegido \\
\hline 1982 & TJRS & Conduta típica + periculosidade social \\
\hline 1984 & TJSP & Valor irrisório \\
\hline 1989 & STF & Afastamento da ilicitude + onerar a atividade jurisdicional \\
\hline 1994 & STJ & Contumácia \\
\hline 1998 & STF & Razoabilidade e proporcionalidade \\
\hline 2000 & STF & Valor mínimo é diferente de pequeno valor \\
\hline 2002 & STF & Perigo presumido \\
\hline 2004 & STF & $\begin{array}{l}\text { O princípio da insignificância pressupõe a concomitância de quatro vetores: } \\
\text { a) a mínima ofensividade da conduta do agente; b) nenhuma periculosidade social } \\
\text { da ação; c) o reduzidíssimo grau de reprovabilidade do comportamento; e } \\
\text { d) a inexpressividade da lesão jurídica provocada. }\end{array}$ \\
\hline 2008 & STF & Fragmentariedade + intervenção mínima do estado \\
\hline 2012 & STF & $\begin{array}{c}\text { CF, ART. 5 } 5^{\circ} \text { XXXIX “NÃO HÁ CRIME SEM LEI ANTERIOR QUE O DEFINA, } \\
\text { NEM PENA SEM COMINAÇÃO LEGAL” + PREÇO OU A EXPRESSÃO } \\
\text { FINANCEIRA DO OBJETO DO DELITO. }\end{array}$ \\
\hline
\end{tabular}

FONTE: ELABORADO PELO AUTOR.

Desse quadro, temos que o primeiro elemento a constituir a construção do sentido de bagatela foi a política criminal, quando o bem jurídico penal traz ao debate o lugar do direito penal para a sociedade, o que envolve, também, a questão da lesividade social. Seguindo a construção de sentido, com a decisão de 1981 do Tribunal de Justiça de Santa Catarina (TJSC), a distinção entre conceito formal e material de delito tematiza o prejuízo material sofrido. Temos, então, que a lesividade social ganha força constitutiva; afinal, o termo delito porta não só a previsibilidade legal, mas 
também a dimensão social. Em 1982, a decisão do Tribunal de Justiça do Rio Grande do Sul (TJRS) tematiza a periculosidade social, debate que põe em relevo não apenas a lesividade da vítima, mas de todo o corpo social, da sociedade mesma. Em 1984, o fato de o valor envolvido ser irrisório tematiza a não exclusividade do valor material, valor pecuniário, e traz ao debate o valor social, e, com isso, o elemento econômico não é suficiente para decidir sobre a aplicabilidade do princípio da insignificância, mas também o valor para a vítima e para a sociedade, portanto quanto ao que cabe ser protegido pelo direito penal. A bagatela envolve a importância, o valor da ação mesma quanto ao autor, à vítima e à sociedade.

Na sequência, a decisão de 1989 do STF, no Habeas Corpus (HC) n. 3.725-3, pauta o afastamento da ilicitude e a questão da onerosidade da prestação jurisdicional. Observamos que o tema da lesividade e da periculosidade social soa "formado", porém insuficiente. Valores presentes em debates sobre acesso à justiça, como os desenvolvidos na sociologia da administração da justiça, quando critérios econômicos, sociais e culturais são apontados como responsáveis por dificultar e afastar demandas sociais no Judiciário (SOUSA SANTOS, 1986, p. 11-32) passam a integrar a bagatela, o mesmo se diga quanto ao valor econômico para o estado quanto às demandas judiciais, no que tange às demandas “irrelevantes" quanto ao bem jurídico, quanto à função social do direito. Em 1996, o STF, no HC n. 70.747, agrega o elemento contumácia, em decisão sobre um caso de atropelamento. $\mathrm{O}$ argumento que conduz à inclusão da contumácia é

18. Pessoas da estirpe do paciente, que não possuem um senso crítico, com freio inibitório dos arroubos da juventude e que, se não fazem parte do imenso rol dos “filhinhos do papai”, dos quais recebem todas as condições para a prática das estripulias e depois o apoio moral quando erram, pelo menos não recebem dos genitores a necessária orientação, somente o império da justiça poderá atingi-los e obstá-los das práticas hoje, de pequenas infrações, amanhã de grande delitos (HC 70.747-5 RS, STF, Relator Francisco Rezek).

Na sequência temos a inclusão da razoabilidade e proporcionalidade com a decisão do STF de 1998, no HC n. 77.003. O tema do valor ínfimo e pequeno valor volta a ter lugar, como lemos na decisão de 2000, do STF, no HC n. 80.095. Chamamos a atenção para esse retorno temático para repisar que o sentido não se sedimenta, não se forma com definitividade, antes, segue aberto, portanto passível de ser alterado. Éo que observamos com essa decisão de 2000. Em 2002, no HCn. 82.324, o STF traz o tema do perigo 
presumido.Éem 2004, com a decisão do STF no HC n. 84.412, que são equacionados os quatro elementos formadores do sentido jurídico de bagatela:

a) a mínima ofensividade da conduta do agente;

b) nenhuma periculosidade social da ação;

c) o reduzidíssimo grau de reprovabilidade do comportamento; $\mathrm{e}$

d) a inexpressividade da lesão jurídica provocada.

Desde então, esses quatro critérios aparecem recursivamente nas decisões dos tribunais estaduais, os quais, até então, recorriam a decisões do Tribunal de Justiça do Estado de São Paulo (TJSP), TJSC e do TJRS. Observamos que as decisões estaduais que negam a aplicação do princípio de bagatela citam decisões do TJSP, porém, quando a decisão aplica o princípio, citam decisões do TJSC e do TJRS. Esses dados nos levam a sugerir que as decisões do TJSP são conservadoras quanto à aplicação do princípio da bagatela, já as do TJSC e TJRS são vanguardistas, no sentido de pioneiros em decisões mutantes do direito. Caberia pesquisar se esse fenômeno se repete quanto a decisões de outras temáticas jurídicas.

Com a decisão de 2008, no HC n. 92.531, e a de 2012, no HC n. 111.017, ambas do STF, observamos que o direito segue construindo o sentido jurídico de bagatela, ou seja, segue retematizando critérios, de maneira que temas são incluídos e excluídos como elementos ao sentido de bagatela. Assim é devido ao paradoxo do sentido (atualidade/potencialidade), justamente devido à temporalidade. O sentido não tem início nem término. Ele não tem origem. Ele nunca está concluído, antes nunca deixará de vivenciar mudanças. O que nos remete à carnavalização do sentido; afinal, não há texto adâmico (BAKHTIN, 1986, 272) tão pouco se pode falar em conclusibilidade como inteireza, completude, fim de um enunciado, mas sim conclusibilidade como elemento temporal de enunciados, portanto como responsividade, com elemento que viabiliza a comunicação, o discurso, uma conversa (BAKHTIN, 1986, p. 280), semelhante ao que lemos com a língua com trabalho social de Marcuschi (2007a, p. 77) e na perspectiva de sentido presente em Luhmann (1998, p. 77-212; 2006, p. 27-40). A construção de sentido é constante, não há um sentido que se sedimenta e que passa a servir de diretriz às decisões futuras, antes, um sentido só tem sentido quando ele mesmo porta um sentido, ou seja, contém elementos que viabilizam a distinção ao mesmo tempo que contém elementos que permitem a inclusão de conteúdos. Para testar essa hipótese, 
- ARTUR STAMFORD DA SILVA

delimitamos a pesquisa a uma temática. Aqui apresentaremos a aplicação do princípio da insignificância para casos envolvendo uso ou porte de entorpecente. Vejamos a sequência de decisões e seus excertos:

[...] ainda que a quantidade de $0,25 \mathrm{~g}$ de maconha apreendida na posse do requerente, não cabe aplicar o princípio da insignificância para estes casos por se tratar de saúde pública (TJSP 1979 HC 12780).

[...] aplica-se a teoria da bagatela porque a ínfima porção da erva seca apreendida, apenas $0,2 \mathrm{~g}$ - 0 que representa uma diminuta quinta parte de uma grama -, não se presta para formar qualquer "fininho", sendo insuscetível para causar dependência concreta a alguém e, em consequência, de duvidosa potencialidade tóxica e perigosidade à saúde pública (TJSC 1981 - HC 25832).

[...] não se reconhece o princípio da insignificância mesmo sendo ínfima a quantia apreendida, pois a lei não cogita de quantidade de droga, apenas visa resguardar a saúde pública (STF, 2003, HC 81641-0).

Paciente preso com 0,25 g de substância entorpecente, tipo canabis sativa, vulgarmente conhecida como maconha. $\mathrm{O}$ porte de quantidade mínima não possui alta periculosidade social, nem lesividade material a bens jurídicos. O princípio da insignificância deve ser aplicado sempre que atendidos os requisitos objetivos, quais sejam: mínima ofensividade da conduta do agente; ausência de periculosidade social da ação; reduzido grau de reprovabilidade do comportamento e inexpressividade da lesão jurídica causada. Nada justifica a desproporção entre tratamento penal que se dá ao usuário civil e ao militar (STF, 2008 - HC 94.809).

Esses excertos indicam o quanto a comunicação jurídica não se reduz a uma decisão, antes envolve a recursividade comunicacional, portanto uma calculabilidade da expansão do valor (Eigen) referenciado, ou seja, sucessivas ocorrências de reentrada da forma na forma, posto que

[...] os lados de cada distinção experimentalmente desenhada têm dois tipos de referência.

O primeiro, ou explícita, se refere ao valor de um lado de acordo com a forma como está marcado. O segundo, ou implícita, se refere a um observador externo. Ou seja, o lado de fora é o lado do qual uma distinção deve ser vista (SPENCER-BROWN, 1969, p. 69). 
Recursividade é expressão matemática desenvolvida pelos teóricos da teoria do caos para explicar como é possível uma máquina não trivial dar resultados calculáveis, ainda que imprevisíveis, trata-se do comportamento Eigen, ou seja, de reconhecibilidade das regularidades (FOERSTER, 2003b, p. 321). Empregado à comunicação humana, recursividade implica pressupor que a comunicação humana implica tomar os seres humanos com máquinas não triviais. O termo máquina está empregado não na conotação de equipamento, coisa, objeto composto de peças interligadas para produzir determinado efeito, mas sim como metáfora referente à complexidade do ser humano, à sua composição de elementos físicos, biológicos, psíquicos e sociais (FOERSTER, 2003b, p. 321). A metáfora máquina não trivial empregada para lidar com a comunicação humana implica admitir que a forma de comunicação humana contém estrutura e ao mesmo tempo variação. Enquanto as máquinas triviais trabalham linearmente as informações que recebem, processando-as e produzindo resultados previstos, nas máquinas não triviais há a autonomia de funcionamento interno, a “cada operação, esse estado interno muda, de modo que, quando a próxima operação ocorre, a operação anterior não é repetida, mas outra operação pode ocorrer” (FOERSTER, 2003b, p. 312).

Recursividade, nesses termos, envolve não uma repetição, uma redundância, mas uma circularidade reflexiva, ou seja, sempre conterá acréscimo de informação. Assim, temos que, com a re-entry e a recursividade, o sistema é capaz de aprendizado, tanto consigo mesmo quanto com seu ambiente; afinal, ao observar, no próprio sistema ocorrem intercâmbios de operações e composições de ordem internas tanto quanto externas ao sistema (FOERSTER, 2003b, p. 308, 319). Trata-se da Eigen Function, Eigen Values, Eigen Behavior, ou seja, da autorreferência, portanto de a comunicação deter sua própria função, seus valores próprios de referência e, inclusive, deter comportamentos próprios no sentido de deter um nível de invariância, o que torna possível a comunicação humana mesma.

A forma de sentido envolve recursividade. Aplicando isso à decisão jurídica como operação do direito, temos que a formação de sentido do direito porta elementos constantes (estrutura) ao mesmo tempo que porta capacidade de mudança (abertura). Assim, não cabe pesar em pesquisar decisão jurídica para conhecer ou estabelecer a decisão a ser tomada, mas apenas probabilidade, calculabilidade recursiva. Em 1978, bagatela era tema novo no direito, os elementos estruturais para dar sentido ao tema exigiram mobilizar questões até além dos princípios do direito; afinal, tematizar o bem jurídico penal, o lugar do direito penal na sociedade, não é um tema de princípio jurídico, mas 
próprio da sociologia do direito; afinal se fala em teoria do controle social penal e de política criminal, como lemos no HC n. 81.641, do STF, decisão proferida em 2003. O recurso à questão da saúde pública explica-se nessa lógica, pois ela não é um princípio jurídico que poderia ser utilizado para afastar a aplicação da bagatela ao uso de droga. Em 1981, considerou-se saúde pública argumento insuficiente ao ponto de ser afastado e se aplicar a bagatela ao caso de porte e apreensão de 0,2 $\mathrm{g}$ de entorpecente (maconha). Nesse ponto, a recursividade ocasionou o afastamento de um argumento, porém não o eliminou, pois ele segue passível de ser evocado futuramente. Em 2003, os ministros do STF retomam o tema da saúde pública para negar a aplicação do princípio da insignificância em caso de apreensão de $0,68 \mathrm{~g}$ de maconha. Esse processo mesmo de incluir, excluir e reincluir um argumento não nos leva a seguir pela via da acusação que os ministros julgam como querem e bem entendem, nem que não há respeito à legislação, nem que houve compra-e-venda de sentença, nem que se trata de corrução sistêmica porque o direito estaria funcionando, selecionado que decisão tomar, sob a intervenção de fatores políticos e econômicos ao ponto de disfarçar sua própria autonomia decisória (LUHMANN, 2005, p. 568). Preferimos lidar com essa situação considerando-a uma questão de aquisição de atualidade do sistema jurídico (LUHMANN, 2005, p. 102), portanto de política do direito mesmo afinal, os envolvidos nos casos analisados sequer são pessoas com poder econômico ou político. Em 2008, o STF, no HC n. 94.809, decide aplicar o princípio da insignificância para casos de uso ou porte de pequena quantidade de maconha. Com isso temos que o sentido jurídico de algo não é o estabelecimento de um conteúdo, a fixação de uma definição. Ainda duvidando dessa conclusão, fizemos o mesmo exercício, agora quanto às decisões relativas à aplicabilidade do princípio da insignificância no âmbito militar.

Observamos, no STF que, quando o caso envolve competência da justiça militar, cabe a ela a decisão de aplicar ou não o princípio da insignificância. Ocorre que, em decisão de 2006, o princípio passa a ser aplicável. Em 2007, mantém-se aplicável, porém, em 2008, volta a não ser aplicável. Até que em 2010 encontramos decisões aplicando e negando sua aplicação. A análise se ocupou em observar que era uma questão de temática, porém o que observamos foi que não, mas sim principiológica mesmo, como se pode verificar das duas decisões de 2010, ambas tratam de uso ou porte de entorpecente em ambiente militar e no HC n. 101.759 MG se admite a aplicação e no HC n. 10.4923 RJ se nega. Considerando o nível de observação organizacional, temos que se trata de STF, porém, se observamos o nível da interação, vemos que os relatores são distintos. Com isso, 
fica a reflexão sobre o lugar da divergência entre opiniões de ministros do STF na construção de sentido do direito, o que nos remete ao tema da legitimação da decisão jurídica.

Semelhante situação lemos no caso da Súmula n. 599: "O princípio da insignificância é inaplicável aos crimes contra a administração pública”, datada de 20 de novembro de 2017, do STJ. Independentemente das controvérsias doutrinárias e decisões na área tributária, quanto a se tomar por insignificante mover ações de execução fiscal para casos inferiores a R $\$ 20$ mil, no Recurso de HC n. 85.272, os ministros da Sexta Turma do STJ relator o ministro Nefi Cordeiro - aos 14 de agosto de 2018, votaram, por unanimidade, pela não aplicação da referida súmula em razão da peculiaridade do caso, decide que

[...] a despeito do teor do enunciado sumular n. 599, no sentido de que o princípio da insignificância é inaplicável aos crimes contra a administração pública, as peculiaridades do caso concreto - réu primário, com 83 anos na época dos fatos e avaria de um cone avaliado em menos de $\mathrm{R} \$ 20,00$, ou seja, menos de $3 \%$ do salário mínimo vigente à época dos fatos - justificam a mitigação da referida súmula, haja vista que nenhum interesse social existe na onerosa intervenção estatal diante da inexpressiva lesão jurídica provocada.

\section{Conclusão}

O que observamos quanto à construção de sentido é que bagatela foi tema aceito, depois passou a ser negado, depois aceito e, atualmente, vem sendo bastante rejeitado, o que nos leva a afirmar o seguinte:

1) a comunicação não tem início nem término;

2) a recursividade do direito permite que ele viva a construção de sentido de sua forma recorrendo à memória jurídica ao mesmo tempo que aberto para aprender com seu ambiente (acoplamento cognitivo e estrutural);

3) a construção de sentido não é linear, mas circular dada a temporalidade do sentido (atual/possível);

4) a decisão jurídica é contingente = poderia ser tomada deferente da que foi tomada;

5) o direito como sistema de sentido de licitude é quem, aplicando seu Eigen Values (lícito/ilícito), promove seu Eigen Behavior (operação recursiva autorreferente) construindo o sentido de direito. 


\section{REFERÊNCIAS}

ARCHER, M. Teoría social realista: el enfoque morfogenético. Tradução Daniel Chernilo. Santiago de Chile: Universidad Alberto Hurtado, 2009.

BAKHTIN, M. Estética da criação verbal. Tradução Paulo Bezerra. São Paulo: Martins Fontes, 1986.

BELVISI, F. Legal argumentation and justice in Luhmann's System Theory of Law. International Journal Semiotics Law, v. 27, n. 2, p. 341-357, 2014. doi:10.1007/s11196-014-9374-9.

FISCHER-LESCANO, A.; CHRISTENSEN, R. Auctoritatis Interpositio: how systems theory deconstructsdecisionismo.Social \& Legal Studies, v.21,n.1,p.93-119,2012.doi:10.1177/0964663911423698.

FOERSTER, H. von. Sistemi che osservano. Roma: Astrolabio, 1987.

FOERSTER, H. von. On self-organizing systems and their environment. In: FOERSTER, H. von. Understanding understanding: essays on cybernetics and cognition. New York: Springer-Verlag. 2003a. p. 1-19.

FOERSTER, H. von. For Niklas Luhmann: "how recursive is communication? In: FOERSTER, H. von. Understanding understanding: essays on cybernetics and cognition. New York: Springer-Verlag, 2003b. p. 305-323.

GARFINKEL, H. Estudos de etnometodologia. Petrópolis: Vozes, 2018.

GOFFMAN, E. Os quadros da experiência social: uma perspectiva de análise. Petrópolis: Vozes, 2012.

HABERMAS, J. Verdad y justificación. Madrid: Trotta, 2002.

HUSSERL, E. Ideias para uma fenomenologia e para uma filosofia fenomenológica. Tradução Márcio Suzuki. Aparecida: Ideias \& Letras, 2006.

KAUFFMAN, L. H. Self-reference and recursive forms. Journal Social Biological Structure, v. 10, p. 53-72, 1987.

KOCH, I. G. V. Desvendando os segredos do texto. São Paulo: Cortez, 2006.

LUHMANN, N. Legal argumentation: an analysis of its form. Modern Law Review, v, 58, n. 3, p. 285-298, May 1995.

LUHMANN, N. La ciencia de la sociedad. Ciudad de México: Universidad Iberoamericana; Barcelona: Herder, 1996.

LUHMANN, N. La ciencia de la sociedad. Ciudad de México: Universidad Iberoamericana; Barcelona: Herder, 1998.

LUHMANN, N. El derecho de la sociedad. Ciudad de México: Universidad Iberoamericana; Barcelona: Herder, 2005.

LUHMANN, N. La sociedad de la sociedad. Ciudad de México: Universidad Iberoamericana; Barcelona: Herder, 2006.

LUHMANN, N. Organización y decisión. Ciudad de México: Universidad Iberoamericana; Barcelona: Herder, 2010. 
MAINGUENEAU, D. Doze conceitos em análise de discurso. São Paulo: Parábola, 2010.

MAINGUENEAU, D. Discurso e análise de discurso. São Paulo: Parábola, 2015.

MAINGUENEAU, D. Retorno crítico sobre ethos. In: MESTI, P. C.; BARONAS, R. L.; CARREON, R. de O. (org.). Análise do discurso: entorno da problemática do ethos, do político e de discursos constituintes. Campinas: Pontes, 2016. p. 13-34.

MARCUSCHI, L. A. Fenômenos da linguagem: reflexões semânticas e discursivas. Rio de Janeiro: Lucerna, 2007a.

MARCUSCHI, L. A. Cognição, linguagem e práticas interacionais. Rio de Janeiro: Lucerna, 2007b.

MARCUSCHI, L. A. Processo de compreensão: produção textual, análise de gêneros e compreensão. São Paulo: Parábola, 2008.

MASCAREÑO, A. Ética da contingência por meio do direito reflexivo. In: STAMFORDDA SILVA, A. (org.). Sociologia do direito: na prática da teoria. Curitiba: Juruá. 2007. p. 203-239.

POSSENTI, S. Notas sobre condições de possibilidade da subjetividade, especialmente na linguagem. Caderno de Estudos Linguísticos, v. 35, p. 95-107, 1998.

POSSENTI, S. Discurso, estilo e subjetividade. São Paulo: Martins Fontes, 2001.

POSSENTI, S. Os limites do discurso. Curitiba: Criar, 2002.

POSSENTI, S. Questões para analistas do discurso. São Paulo: Parábola, 2009.

RORTY, R. Verdade e progresso. São Paulo: Manole, 2005.

SCHMITT, C. O guardião da constituição. São Paulo: Del Rey, 2007.

SOUTO, C. For a general theoretical unified axiomatic reduction of the natural spaces. Revista Brasileira de Sociologia do Direito, v. 6, n. 2, p. 2-12, 2019. Disponível em: http://revista.abrasd.com.br/ index.php/rbsd/article/view/327/188. Acesso em: 17 nov. 2020.

SOUTO, C.; SOUTO, S. Sociologia do direito: uma visão substantiva. Porto Alegre: Safe, 2003.

SPENCER-BROWN, G. Laws of form. London: George Allen and Unwin, 1969.

STAMFORD DA SILVA, A. Sociologia da decisão jurídica: pesquisa qualitativa sobre semântica social da comunidade jurídica. In: STAMFORD DA SILVA, A. (org.). Sociologia do direito: na prática da teoria. Curitiba: Juruá, 2007.p. 303-346.

STAMFORD DA SILVA, A. Gödelização da racionalidade e o limite da decisão jurídica: desparadoxizando as dicotomias da hermenêutica desde a teoria dos sistemas de sentido com Niklas Luhmann. Revista Acadêmica da Faculdade de Direito do Recife, n. LXXXI, p. 113-137, 2009.

STAMFORD DA SILVA, A. Decisão jurídica e mudança social. Para uma sociologia da decisão jurídica. Revista Confluências, Rio de Janeiro, n. 11, p. 121-150, 2010.

STAMFORD DA SILVA, A. Decisión judicial y cambios sociales en la óptica de la teoría de sistemas de sentido social. In: CADENAS, H.; MARCAREÑO, A.; USQUIZA, A. (ed.). Niklas Luhmann y el legado universalista de su teoría. Santiago de Chile: RIL, 2012a. p. 267-316. 
- ARTUR STAMFORD DA SILVA

STAMFORD DA SILVA, A. Teoria reflexiva da decisão jurídica: observações a partir da teoria dos sistemas que observam. In: SCHWARTZ, G. (org.). Juridicização das esferas sociais e fragmentação do direito na sociedade contemporânea. Porto Alegre: Livraria do Advogado, 2012b. p. 29-58.

STAMFORD DA SILVA, A. Sociologia da decisão jurídica: aplicação ao caso da homoafetividade. Revista Brasileira de Sociologia do Direito, v. 1, n. 1, p. 66-85, 2014. Disponível em: http://revista.abrasd. com.br/index.php/rbsd/article/view/37/47. Acesso em: 17 nov. 2020.

STAMFORD DA SILVA, A. Teoria reflexiva da decisão jurídica: direito, mudança social e movimentos sociais. Revista de Direito da UnB, v. 1, n, 2, p. 27-52, 2016. Disponível em: https://periodicos.unb. br/index.php/revistadedireitounb/article/view/24522/21711. Acesso em: 17 nov. 2020. 